Egyptian Journal of Aquatic Biology \& Fisheries

Zoology Department, Faculty of Science,

Ain Shams University, Cairo, Egypt.

ISSN $1110-6131$

Vol. 23(4): 451 - 464 (2019)

www.ejabf.journals.ekb.eg

\title{
Feeding on phytoplankton profile of two African Cichlids in large reservoir, Lake Nasser, Egypt
}

\author{
Abd-Ellatif M. Hussian ${ }^{1}$, Walid Aly ${ }^{2} *$ and Hanaa H. Morsi ${ }^{3}$ \\ 1- Freshwater and Lakes Division, National Institute of Oceanography and Fisheries \\ (NIOF), Cairo, Egypt. \\ 2- Fisheries Division, National Institute of Oceanography and Fisheries (NIOF), \\ Cairo, Egypt \\ 3- Botany Department, Faculty of Science, Menoufia University, Egypt. \\ * Corresponding author, e-mail: walid.soton@gmail.com
}

\section{ARTICLE INFO}

\section{Article History:}

Received: July 1, 2019

Accepted: Oct. 26, 2019

Online: Nov. 2019

\section{Keywords:}

Lake Nasser

Fisheries

Feeding

Phytoplankton

Oreochromis niloticus

Sarotherodon galilaeus

\section{ABSTRACT}

This study was carried out in 2016 to investigate the feeding on phytoplankton profile of the Nile tilapia (Oreochromis niloticus) and mango tilapia (Sarotherodon galilaeus) inhabiting Lake Nasser, and its relation to their fisheries biological parameters. Phytoplankton Preference index (PPI), Index of Relative Importance (IRI), and Straus Linear index were used to investigate the feeding patterns of the two species in the lake. Moreover, some fish biological parameters of the two species were determined in the lake different areas. The results showed that $O$. niloticus and S. galilaeus feed mainly on the same phytoplankton items. Bacillariophyceae was identified as the most desired phytoplankton item to O. niloticus (IRI = 12.53) and $S$. galilaeus (IRI=18.28). Both fish species were more selective to five species from Bacillariophyceae and five species from Chlorophyceae, while they were more avoidant to four species from Cyanophyceae at all lake's areas. The results also showed that the main fisheries biological parameters are varied significantly between the two species and through lake different areas. This study concluded that the variation in fisheries biological parameters in Lake Nasser is not related to the pattern of feeding on phytoplankton but is led by other factors (e.g. fishing practices).

\section{INTRODUCTION}

Lake Nasser is an extremely dynamic aquatic ecosystem which is an important source of fish for Aswan Governorate and the rest of Egypt. Although 75 fish species have been recorded in the Nile system (Bishai and Khalil, 1997), the fisheries sector of Lake Nasser depends on only a limited number of species, consequently, cichlids constituted 67 percent, 12315 tonnes, of the production of the lake which was 18352 tonnes in 2016 (GAFRD, 2018).

The natural aquatic habitats provide a vast diversity of organisms of different sizes and taxonomy groups that are utilised as food by fish (Gerking, 2014). The investigation of fishes diet in their natural habitats improves the understanding of their distribution, abundance, growth, and productivity (Ekpo et al., 2014). Consequently, investigating the food and feeding habits of the commercial fish species is a very 
important concern since it establishes the basis for the development of effective fisheries management programmes (Oronsaye et al., 2005). Food and feeding habits studies are mostly based on the analysis of gut contents of fish caught from their natural habitats, since the study of the gut content is not only a method to know the diet but also an excellent source of information on many characteristics of fish biology and ecology (Manko, 2016).

Fishes have been known to feed on a wide variety of items such as phytoplankton, detritus, higher plant material, chironomids, zooplankton and fish (Omondi et al., 2011; Shalloof and Khalifa, 2009; YalÇIn et al., 2001). The feeding habits of fish may be varying according to age and size (Tadesse, 1998), as the sizes of the fish increases, the consumption of large quantities of various phytoplankton evidently increased (Getachew, 1987).

Phytoplankton is the basic link in aquatic food chain, in addition to play an essential role as food material for fishes and its fry (Borowitzka and Borowitzka, 1988). Fish production in a lake depends directly on its productivity (Saiyida and Bari, 1982).

On the other hand, the main fisheries biological parameters such as length, weight and condition factor are used in order to compare the "condition", "fatness" or wellbeing of fish. They are strongly influenced by both biotic and abiotic environmental conditions and can be used as an index to assess the status of the aquatic ecosystem in which fish live (Anene, 2005).

Despite the importance of investigating the spatial variation of different biological factors affecting fish populations in such a huge water body like Lake Nasser, information about food and feeding habitats and fisheries biological parameters of fish species in Lake Nasser is outdated or completely absent. All available information on these aspects is more than decade old and on the lake as whole without considering any variation in the conditions through different regions of the lake (Halls et al., 2015).

Therefore, this study aimed to contribute to the available information on food and feeding habitats of two of the most economically and ecologically important fish species inhabiting Lake Nasser, Nile tilapia (Oreochromis niloticus) and mango tilapia (Sarotherodon galilaeus). This study is focused on phytoplankton since they were ranked as the food items with the highest occurrence in the stomach of these fish species (Shalloof and Khalifa, 2009; Teferi et al., 2000; Saiyida and Bari, 1982; Getachew, 1987). Moreover, this work investigates how feeding profile on phytoplankton is related to the main fisheries biological parameters of the two fish species in the Lake.

\section{MATERIALS AND METHODS}

\section{Study Area}

Lake Nasser is a huge man made reservoir located on the south border of Egypt with Sudan (Hussian et al., 2015). Its surface area is $5237 \mathrm{~km}^{2}$ at its highest water level and extends in Egypt for $291.8 \mathrm{~km}$ from South to North (Halls et al., 2015). Lake Nasser could be divided to three main sectors: northern sector which shows full lake characteristics, middle sector which has both lake and river characteristics and southern sector which is dominated by riverine characteristics. There are 85 dendritic inlets in the lake, known as khors, which are significantly variable in size and shape, and greatly increase the shoreline length (Halls et al., 2015). 


\section{Sampling}

In the present study, sampling took place during December 2016. Six sites were selected to represent the different sectors of the lake: Elsag, Dihmit and Mirwaw in the north sector, Amda and ElMadiq in the middle sector, and Tushka in the south sector (Figure 1).

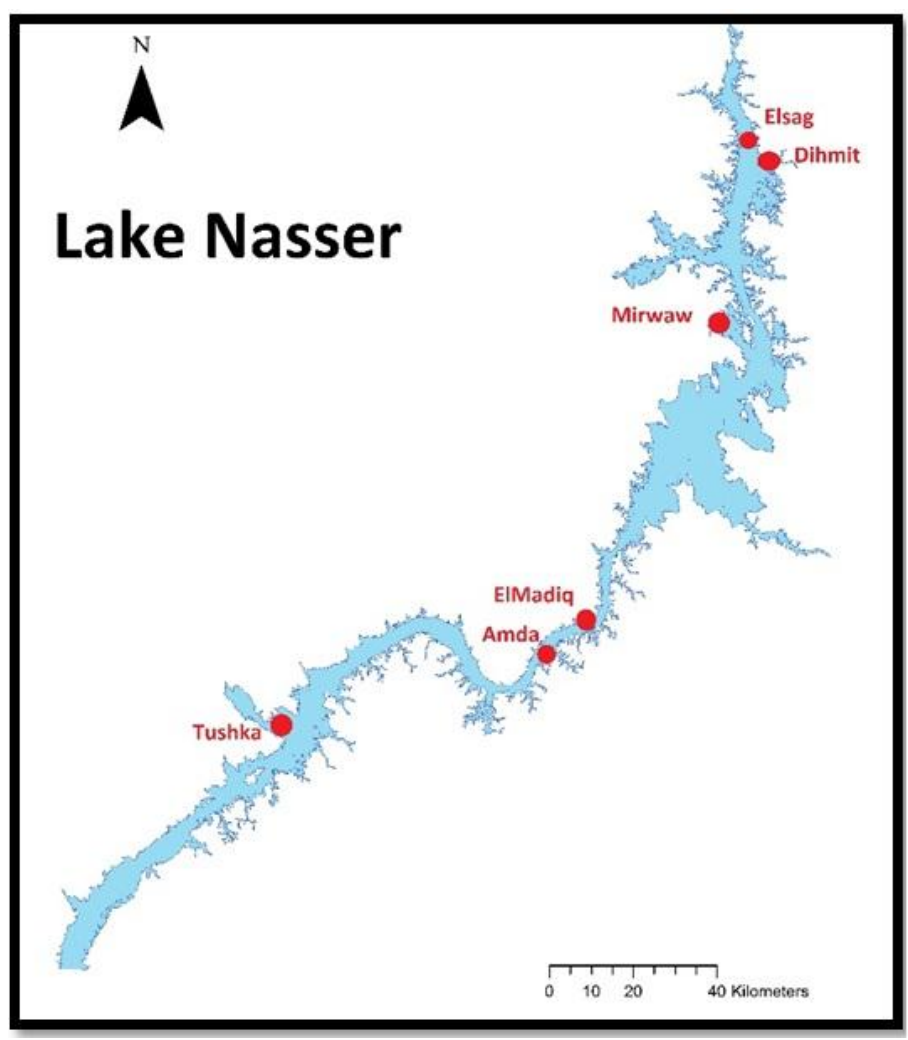

Fig. 1: A map of Lake Nasser showing the sampling sites.

\section{Sampling of Phytoplankton}

One litter of water was collected from the different sites and preserved in $4 \%$ formalin for quantitative and qualitative analyses of phytoplankton (Vollenweider et al., 1974). In the laboratory, the preserved samples were transferred to a glass cylinder. Phytoplankton cells were allowed to settle for 5 days (APHA, 1998), siphoned and concentrated to a fixed volume and transferred to plastic vials for microscopic examination. The drop method was applied for counting and identifying phytoplankton species (APHA, 1998). Triplicate samples $(5 \mu \mathrm{l})$ were taken and examined under an inverted microscope (ZEISS 1M4738) at magnifications of 400x and 1000x. Reference manuals were used for the identification (Compère, 1991; Bourrelly, 1981; Tiffany and Britton, 1952; Prescott, 1978; Starmach, 1974) and (Desikachary, 1959).

\section{Sampling of Fish}

A total of 275 fish belonging to the two fish species $O$. niloticus and S. galilaeus were collected from different sectors of the lake using commercial fishing gears (trammel nets). Total length of each fish was taken to the nearest millimetre from the tip of the snout (mouth closed) to the extended tip of the caudal fin using a measuring board. Body weight was measured to the nearest 0.1 gram using a top loading balance.

\section{Stomach Content Examination}

Fifty-seven fish were dissected and the guts were removed, transferred to labelled containers, and preserved in $4 \%$ formalin fixative then transported to 
laboratory for investigation. In the laboratory, the benches were cleaned and disinfected with hypochlorite solution. The stomach contents were emptied into Petri dish and the food composition was identified by microscope (Windell and Bowen, 1978). For the purpose of microscopic analysis, subsample was taken for phytoplankton enumeration using a teat pipette. This was placed in a Sedgewick rafter cell which carries a volume of $1 \mathrm{ml}$. The food items were then enumerated under a compound inverted microscope (magnification $10 \mathrm{X}$ to $400 \mathrm{X}$ ). The phytoplankton in the stomach contents was counted by the transect method using the procedures outlined in (Lind, 1974).

The gut contents were analysed using frequency of occurrence and numerical methods as described by (Hyslop, 1980). In the frequency of occurrence method, the occurrence of food items was expressed as the percentage of the total number of stomach containing food. In the numerical method, the number of each food item was expressed as the percentage of the total number of food items found in the stomach.

\section{Data Analysis}

\section{Phytoplankton Preference index (PPI)}

For determine the phytoplankton preference index, percentage frequency of occurrence was obtained through the following equation described by (Chrisafi et al., 2007): $\mathrm{PP}=$ (number of stomachs with a specific phytoplankton species/the number of non-empty stomachs from phytoplankton) $\times 100$. The different values of this index, allow separation of phytoplankton preference to three categories: If PP $>50 \%$, the specific phytoplankton species is dominant and it is the main diet. If $50 \%>\mathrm{PP}>10 \%$, the specific phytoplankton species is secondary. If $\mathrm{PP}<10 \%$, the specific phytoplankton species is eaten accidentally (Euzen, 1987).

\section{Index of Relative Importance (IRI)}

In the gut content, IRI for phytoplankton classes was calculated according to (Pinkas et al., 1970), the following formula: IRI $=(\% \mathrm{~N}+\% \mathrm{~V}) \% \mathrm{O}$. Where, $\mathrm{N}, \mathrm{V}$, and $\mathrm{O}$ represent percentages of number, volume and frequency of occurrence of phytoplankton, respectively.

\section{Straus Linear index}

Phytoplankton was obtained from the gut samples and from the water samples then identified according to (APHA, 1998) for calculation of The Straus Linear index based on the following equation;

$\mathrm{L}_{\mathrm{i}}=\mathrm{r}_{\mathrm{i}}-\mathrm{p}_{\mathrm{i}}$ (Strauss, 1979)

Where: $r i$ is the proportion of phytoplankton taxon $i$ in the guts of predators and $p_{i}$ is the proportion of the same taxon in the environment. The means of ri and pi evaluated by the number of phytoplankton in each sample will be used to calculate $\mathrm{L}_{\mathrm{i}}$

\section{Fisheries biological parameters}

A total of 275 individuals belonging to the two commercial fish species $O$. niloticus and $S$. galilaeus were used to calculate $\mathrm{K}$ in this study. Both species were represented by at least 15 individuals in each sector of the lake and with a relatively wide size range to carry out the ANOVA and Tukey's (HSD) tests. Extreme outliers attributed to data collection error were omitted from the analyses. Condition factor (K) was calculated by the formula: $\mathrm{K}=100 \mathrm{~W} / \mathrm{L}^{3}$ (Pauly, 1983). Variations in total length, total weight, and $\mathrm{K}$ of the individual fish living in the lake's different sectors were analysed with one-way analyses of variance (ANOVA) with subsequent Tukey's honestly significant difference (HSD) tests using Xlstat software. All the statistical analyses were considered at significance level of $5 \%(\mathrm{p}<0.05)$. 


\section{RESULTS}

In the present study, stomach content analysis of $O$. niloticus and S. galilaeus revealed a variation in the percentage of different phytoplankton classes (Figures 2 and 3). The dominant phytoplankton classes at the different lake sectors were



Bacillariophyceae followed by Chlorophyceae. Also, Bacillariophyceae was the dominant class in the water column.

Fig. 2: Percentage of phytoplankton classes in gut of Oreochromis niloticus at the different sectors of Lake Nasser



Fig. 3: Percentage of phytoplankton classes in gut of Sarotherodon galilaeus at the different sectors of Lake Nasser

\section{Index of Relative Importance (IRI)}

Calculating the Index of Relative Importance (IRI) for phytoplankton classes, that were recorded in the guts of $O$. niloticus and $S$. galilaeus, revealed that the highest IRI value was observed for Bacillariophyceae followed by Chorophyceae then Cyanophyceae with the mean IRI values of 12.53, 4.90, 2.10 and 18.28, 5.12, 1.90 for both $O$. niloticus and S. galilaeus, respectively, as shown in Table 1.

Table 1: Index of Relative Importance (IRI) for phytoplankton classes which examined in the gut of Oreochromis niloticus and Sarotherodon galilaeus at different sectors during December 2016.

\begin{tabular}{|c|c|c|c|c|c|c|}
\hline \multirow{2}{*}{ Fish species } & \multirow{2}{*}{ Sites } & \multicolumn{5}{|c|}{ IRI } \\
\hline & & Bacillariophyceae & Chlorophyceae & Cyanophyceae & Dinophyceae & Chrysophyceae \\
\hline \multirow{3}{*}{ O.n. } & Sector 1 & 3.60 & 0.62 & 0.46 & 0.08 & 0.07 \\
\hline & Sector 2 & 14.57 & 3.76 & 2.15 & 0.06 & 0.00 \\
\hline & Sector 3 & 19.42 & 10.34 & 3.69 & 0.00 & 0.00 \\
\hline \multicolumn{2}{|c|}{ Mean IRI } & 12.53 & 4.90 & 2.10 & 0.05 & 0.02 \\
\hline \multirow{3}{*}{ S.g. } & Sector 1 & 3.91 & 1.27 & 0.41 & 0.02 & 0.00 \\
\hline & Sector 2 & 14.84 & 4.12 & 1.01 & 0.05 & 0.00 \\
\hline & Sector 3 & 36.09 & 9.98 & 4.29 & 0.91 & 0.00 \\
\hline \multicolumn{2}{|c|}{ Mean IRI } & 18.28 & 5.12 & 1.90 & 0.33 & 0.00 \\
\hline
\end{tabular}


The ANOVA with subsequent HSD tests of the IRI results showed that only the variation of IRI of Chlorophyceae between different lake sectors was statistically significant (Table 2).

Table 2: ANOVA with subsequent HSD tests of the Index of Relative Importance (IRI) for phytoplankton classes which recorded in the guts of Oreochromis niloticus and Sarotherodon galilaeus

\begin{tabular}{|l|r|r|r|r|r|}
\hline & Bacillariophyceae & Chlorophyceae & Cyanophyceae & Dinophyceae & Chrysophyceae \\
\hline Sector 3 & $27.756 \mathrm{a}$ & $10.158 \mathrm{a}$ & $3.986 \mathrm{a}$ & $0.456 \mathrm{a}$ & $0.000 \mathrm{a}$ \\
\hline Sector 2 & $14.703 \mathrm{a}$ & $3.939 \mathrm{~b}$ & $1.579 \mathrm{a}$ & $0.057 \mathrm{a}$ & $0.000 \mathrm{a}$ \\
\hline Sector 1 & $3.755 \mathrm{a}$ & $0.943 \mathrm{c}$ & $0.432 \mathrm{a}$ & $0.053 \mathrm{a}$ & $0.038 \mathrm{a}$ \\
\hline Pr $>\mathrm{F}$ & 0.181 & 0.005 & 0.082 & 0.622 & 0.486 \\
\hline Significant & $\mathrm{No}$ & $\mathrm{Yes}$ & $\mathrm{No}$ & $\mathrm{No}$ & $\mathrm{No}$ \\
\hline
\end{tabular}

\section{Straus Linear food selectivity index for phytoplankton classes}

Straus Linear index of selection showed that $O$. niloticus and $S$. galilaeus were preferential to Bacillariophyceae and Chlorophyceae (positive values) and avoidant to Cyanophyceae and Dinophyceae (negative values) in their diet at all lake sectors (Figs. 4 and 5).



Fig. 4: Straus Linear food selectivity index for phytoplankton classes in gut content of Oreochromis niloticus at different sectors of Lake Nasser.

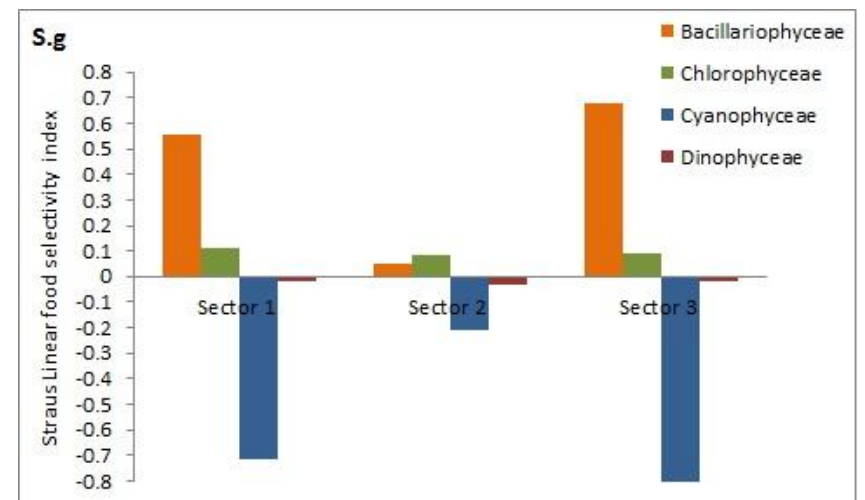

Fig. 5: Straus Linear food selectıvity index tor phytoplankton classes in gut content of Sarotherodon galilaeus at different sectors of Lake Nasser. 


\section{Straus Linear food selectivity index for phytoplankton species}

The stomach content indicated that, O. niloticus in Lake Nasser is more selective to Achnanthes lanceolata v.dubia, Cymbella parva, Synedra ulna and Tabellaria fenestrate from Bacillariophyceae and Chlorella vulgaris, Pediastrum simplex, Scenedesmus arvernensis and Staurastrum paradoxum from Chlorophyceae and more avoidant to Gomphosphaeria aponina, Merismopedia glauca and Microcystis wesenbergii from Cyanophyceae at all lake sectors (Figure 6). Straus Linear food selectivity index for phytoplankton species in the gut content of $S$. galilaeus from different lake sectors showed that species of Achnanthes lanceolata v.dubia, Cymbella parva, Fragilaria capunica and Tabellaria fenestrate from Bacillariophyceae and Chlorella vulgaris, Carteria multifilis from Chlorophyceae are preferable by $S$. galilaeus, while species of Aphanothece stagnina and Microcystis wesenbergii are avoided at all lake sectors (Figure 7).



Fig. 6: Straus Linear food selectivity index for phytoplankton species in gut content of Oreochro: niloticus at different sectors of Lake Nasser.

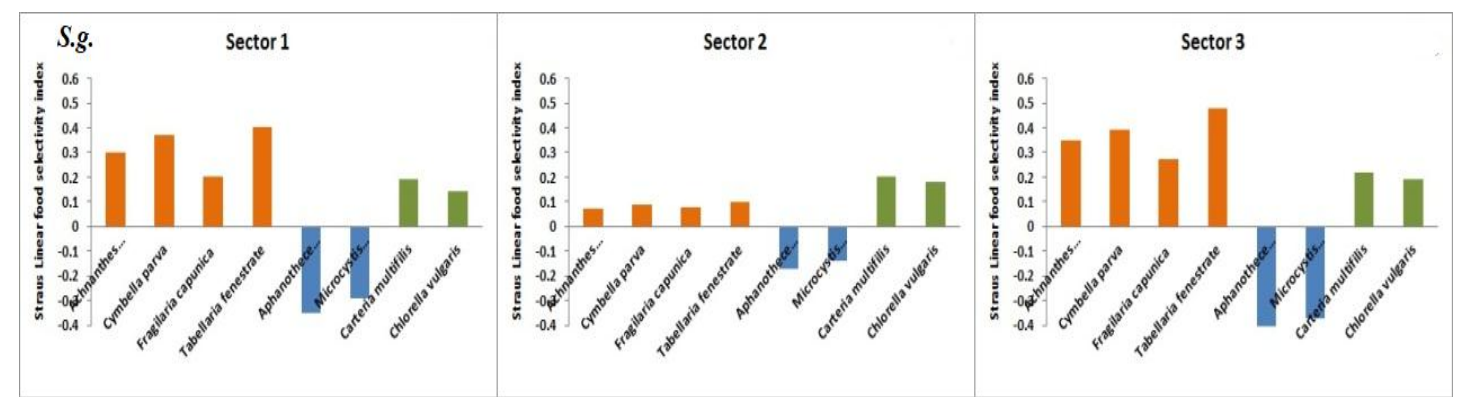

Figure 7: Straus Linear food selectivity index for phytoplankton species in gut content of Sarotherodon galilaeus at different sectors of Lake Nasser.

Table 3 shows the list of phytoplankton species which recorded in the gut contents of $O$. niloticus and S. galilaeus, with Phytoplankton Preference Index (PPI) at the different sectors.

\section{Fisheries biological parameters}

The number of specimens, condition factor, mean length, and mean weight of studied fish species are presented in Table 4. The sample size for the fish species varied from 118 in $O$. niloticus to 157 in $S$. galilaeus. The average condition factor (K) for $O$. niloticus was 2.152 while it was 2.117 for $S$. galilaeus.

An ANOVA revealed significant differences $(\mathrm{P}<0.05)$ in biological parameters among the two species and the three sectors (Table 4). As ANOVA has shown an overall statistically significant difference in species and sectors total length, total weight and condition factor means, Tukey's (HSD) tests were run to confirm where the differences occurred by pairwise comparisons for locations. The results of both statistical analyses are shown in Table 4. The Tukey's (HSD) test showed that sector 1 (north) of the lake was always significantly varied from sector 3 (south) in all tested 
parameter which reveals that there are geographical variations of the studied fisheries biological parameters in Lake Nasser. The average values of all investigated biological parameters were always higher in sector 3 (south).

Table 3: List of phytoplankton species in gut of Oreochromis niloticus and Sarotherodon galilaeus with Phytoplankton Preference Index (PPI) at the different sectors of Lake Nasser.

\begin{tabular}{|c|c|c|c|c|c|c|}
\hline \multirow[t]{2}{*}{ List of species } & \multicolumn{3}{|c|}{ Oreochromis niloticus } & \multicolumn{3}{|c|}{ Sarotherodon galilaeus } \\
\hline & Sector 1 & Sector 2 & Sector 3 & Sector 1 & Sector 2 & Sector 3 \\
\hline Bacillariophyceae & PPI & PPI & PPI & PPI & PPI & PPI \\
\hline Achnanthes clevei v.rostrata & 36.4 & 83.3 & 67.0 & 77.8 & 50.0 & 100.0 \\
\hline Achnanthes lanceolata v.dubia & 91.0 & 100.0 & 100.0 & 100.0 & 83.3 & 100.0 \\
\hline Achnanthes microcephala & 0.0 & 0.0 & 33.3 & 0.0 & 0.0 & 0.0 \\
\hline Amphipleura pellucida & 0.0 & 0.0 & 0.0 & 38.9 & 0.0 & 100.0 \\
\hline Amphora ovalis & 0.0 & 33.3 & 0.0 & 50.0 & 50.0 & 0.0 \\
\hline Anomoeoneis brachysira v.genuina & 0.0 & 33.3 & 0.0 & 16.7 & 0.0 & 0.0 \\
\hline Anomoeoneis sphaerophora v.scalpata & 0.0 & 16.7 & 0.0 & 5.6 & 0.0 & 0.0 \\
\hline Anomoeoneis vitrea & 0.0 & 0.0 & 0.0 & 38.9 & 16.7 & 50.0 \\
\hline Cymbella parva & 100.0 & 100.0 & 100.0 & 100.0 & 83.3 & 100.0 \\
\hline Fragilaria capunica & 54.5 & 100.0 & 0.0 & 100.0 & 66.7 & 100.0 \\
\hline Fragilaria capunica & 0.0 & 0.0 & 0.0 & 0.0 & 0.0 & 0.0 \\
\hline Fragilaria construens & 0.0 & 100.0 & 0.0 & 0.0 & 0.0 & 50.0 \\
\hline Fragilaria crotonensis & 0.0 & 0.0 & 0.0 & 0.0 & 50.0 & 0.0 \\
\hline Fragilaria pinnata & 0.0 & 83.3 & 0.0 & 0.0 & 0.0 & 50.0 \\
\hline Gomphoneis herculeana & 18.2 & 0.0 & 0.0 & 0.0 & 0.0 & 0.0 \\
\hline Gomphonema lanceolatum v.genuinum & 0.0 & 0.0 & 0.0 & 5.6 & 0.0 & 0.0 \\
\hline Gomphonema parvulum v.genuinum & 0.0 & 33.3 & 0.0 & 0.0 & 0.0 & 0.0 \\
\hline Gyrosigma scalproides & 0.0 & 0.0 & 0.0 & 55.6 & 0.0 & 0.0 \\
\hline Mastogloia lacutris v. amphicephala & 4.5 & 0.0 & 0.0 & 33.3 & 16.7 & 50.0 \\
\hline Melosira granulate & 0.0 & 83.3 & 0.0 & 27.8 & 0.0 & 50.0 \\
\hline Melosira varians & 18.2 & 100.0 & 75.0 & 88.9 & 0.0 & 100.0 \\
\hline Navicula accomoda & 0.0 & 0.0 & 0.0 & 0.0 & 16.7 & 0.0 \\
\hline Navicula cocconiformis & 45.5 & 100.0 & 0.0 & 100.0 & 66.7 & 100.0 \\
\hline Navicula cuspidate & 4.5 & 33.3 & 0.0 & 44.4 & 0.0 & 100.0 \\
\hline Navicula radiosa & 77.3 & 100.0 & 0.0 & 100.0 & 0.0 & 100.0 \\
\hline Navicula tripunctata & 31.8 & 50.0 & 0.0 & 0.0 & 0.0 & 0.0 \\
\hline Nitzschia acicularis v. typical & 0.0 & 0.0 & 0.0 & 27.8 & 0.0 & 50.0 \\
\hline Pinnularia borealis & 0.0 & 0.0 & 0.0 & 0.0 & 0.0 & 50.0 \\
\hline Rhoicosphenia curvata & 0.0 & 0.0 & 0.0 & 77.8 & 50.0 & 100.0 \\
\hline Rhopalidia gibba & 27.3 & 33.3 & 0.0 & 0.0 & 0.0 & 0.0 \\
\hline Synedra ulna & 95.5 & 100.0 & 100.0 & 11.1 & 0.0 & 50.0 \\
\hline Synedra acus & 50.0 & 100.0 & 67.0 & 94.4 & 16.7 & 100.0 \\
\hline Tabellaria fenestrate & 100.0 & 100.0 & 100.0 & 100.0 & 100.0 & 100.0 \\
\hline \multicolumn{7}{|l|}{ Chlorophyceae } \\
\hline Ankistrodesmus fusiformis & 0.0 & 0.0 & 0.0 & 38.9 & 0.0 & 50.0 \\
\hline Ankistrodesmus spiralis & 0.0 & 33.3 & 0.0 & 61.1 & 0.0 & 0.0 \\
\hline Asterococcus superbus & 0.0 & 0.0 & 0.0 & 0.0 & 16.7 & 0.0 \\
\hline Botryococcus braunii & 0.0 & 0.0 & 0.0 & 44.4 & 0.0 & 50.0 \\
\hline Carteria multifilis & 31.8 & 100.0 & 67.0 & 100.0 & 83.3 & 100.0 \\
\hline Chlamydomonas bicocca & 13.6 & 100.0 & 33.3 & 61.1 & 66.7 & 0.0 \\
\hline Chlorella vulgaris & 77.3 & 100.0 & 100.0 & 100.0 & 50.0 & 100.0 \\
\hline Chlorococcum humicola & 0.0 & 0.0 & 0.0 & 11.1 & 66.7 & 0.0 \\
\hline Closterium venus & 40.9 & 0.0 & 67.0 & 77.8 & 0.0 & 0.0 \\
\hline Coelastrum cambricum & 0.0 & 0.0 & 0.0 & 5.6 & 0.0 & 0.0 \\
\hline Coelastrum microporum & 54.5 & 66.7 & 0.0 & 0.0 & 0.0 & 0.0 \\
\hline Cosmarium botrytis & 31.8 & 83.3 & 67.0 & 66.7 & 66.7 & 50.0 \\
\hline Cosmarium depressum & 0.0 & 100.0 & 33.3 & 94.4 & 0.0 & 100.0 \\
\hline Cosmarium reniforme & 0.0 & 16.7 & 0.0 & 61.1 & 50.0 & 0.0 \\
\hline Dictyosphaerium pulchellum & 0.0 & 16.7 & 0.0 & 0.0 & 0.0 & 0.0 \\
\hline Elakatothrix biplex & 9.1 & 83.3 & 0.0 & 5.6 & 0.0 & 0.0 \\
\hline Euastrum elegans & 0.0 & 0.0 & 0.0 & 44.4 & 33.3 & 50.0 \\
\hline Eudorina elegans & 4.5 & 16.7 & 0.0 & 0.0 & 0.0 & 0.0 \\
\hline Hyalotheca тисова & 0.0 & 0.0 & 0.0 & 55.6 & 0.0 & 0.0 \\
\hline Kirchneriella microscopica & 0.0 & 66.7 & 0.0 & 0.0 & 0.0 & 0.0 \\
\hline Mesostigma viride & 13.6 & 100.0 & 33.3 & 0.0 & 0.0 & 0.0 \\
\hline Nephrocytium limneticum & 4.5 & 33.3 & 0.0 & 0.0 & 0.0 & 0.0 \\
\hline Oocystis lacustris & 9.1 & 83.3 & 33.3 & 0.0 & 0.0 & 0.0 \\
\hline Pandorina morum & 18.2 & 0.0 & 33.3 & 33.3 & 0.0 & 0.0 \\
\hline Pediastrum duplex & 0.0 & 50.0 & 0.0 & 11.1 & 0.0 & 0.0 \\
\hline Pediastrum simplex & 54.5 & 100.0 & 100.0 & 77.8 & 0.0 & 0.0 \\
\hline
\end{tabular}




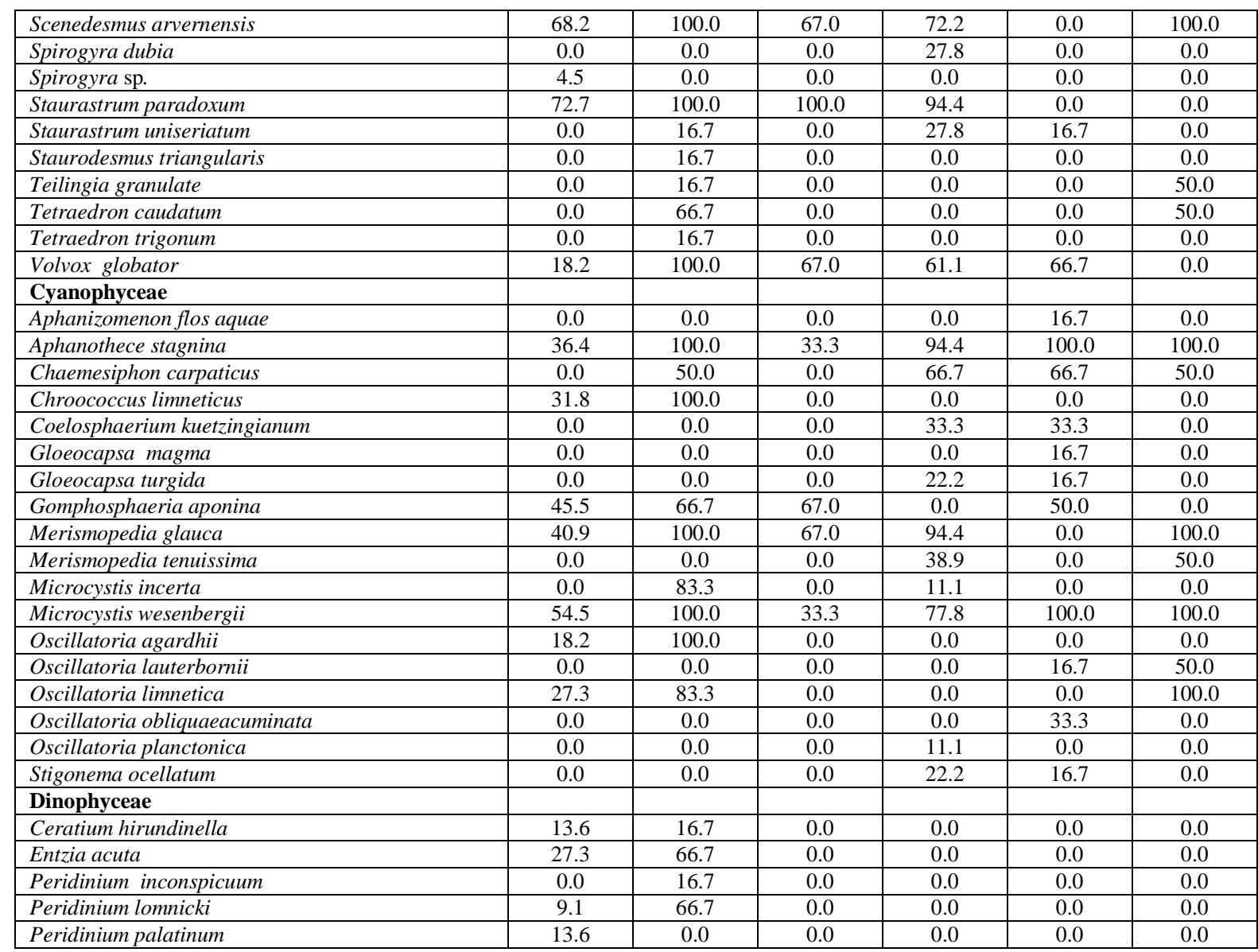

If PP $>50 \%$, the specific phytoplankton species is the main diet

If $50 \%>\mathrm{PP}>10 \%$, the specific phytoplankton species is secondary

If $\mathrm{PP}<10 \%$, the specific phytoplankton species is eaten accidentally

Table 4: The results of ANOVA with subsequent HSD tests of studied biological parameters (Total Length (TL), Total weight (TWt), and condition factor (K)).

\begin{tabular}{|l|r|r|r|}
\hline & T.L. & T.wt. & \multicolumn{1}{l|}{ K } \\
\hline Sector 3 & $26.216 \mathrm{a}$ & $459.064 \mathrm{a}$ & $2.197 \mathrm{a}$ \\
\hline Sector 2 & $25.311 \mathrm{a}$ & $390.335 \mathrm{ab}$ & $2.126 \mathrm{~b}$ \\
\hline Sector 1 & $23.423 \mathrm{~b}$ & $331.181 \mathrm{~b}$ & $2.080 \mathrm{~b}$ \\
\hline Pr> F & 0.000 & 0.000 & 0.000 \\
\hline Significant & Yes & Yes & Yes \\
\hline O.n. & $28.001 \mathrm{a}$ & $544.860 \mathrm{a}$ & $2.152 \mathrm{a}$ \\
\hline S.g. & $21.966 \mathrm{~b}$ & $242.194 \mathrm{~b}$ & $2.117 \mathrm{a}$ \\
\hline Pr>F & O.000 & 0.000 & 0.000 \\
\hline Significant & Yes & Yes & Yes \\
\hline
\end{tabular}

\section{DISCUSSION}

This study shows that phytoplankton is the most common food items for both $O$. niloticus and $S$. galilaeus and that they could be considered as phytoplanktivorous or herbivorous feeders. Moreover, it reports that the most desirable food of plant origin for the two species were diatoms and green algae and states that they favour diatoms than the green algae, despite the latter being more abundant in the aquatic environment. Phytoplankton appeared to be the dominant plant material in gut 
contents of herbivorous fish (Saiyida and Bari, 1982). Some studies classified $O$. niloticus as herbivorous that favourite to phytoplankton species such as diatoms, green and blue green algae (Assefa and Getahun, 2015; Abdulhakim et al., 2015; Bwanika et al., 2004; Teferi et al., 2000) or obligatory herbivore (Gwahaba, 1973). Also, earlier studies in various lakes showed that $O$. niloticus is capable of using a wide range of food resources including algae (Njiru et al., 2004; Shalloof and Khalifa, 2009; Getabu, 1994), in addition to O. niloticus able to shifting feeding behaviour according to the availability of natural foods as well (Njiru et al., 2004; Canonico et al., 2005; Abidemi-Iromini, 2019).

The study also found that $O$. niloticus and $S$. galilaeus fed on the same food items. Both fish species favour Bacillariophyceae, this result supported by (AbidemiIromini, 2019; Abdel-Tawwab, 2003) who mentioned that Bacillariophyceae the most prevailing food items and the high desired by $O$. niloticus, and also Chlorophyceae, this could be attributed to the fact that Chlorophyceae have pleasant cell walls that are easier to digest (Otieno et al., 2014) and they are avoid to Cyanophyceae may be return to Cyanophyceae are filamentous and hence more difficult to handle during feeding and can lead to clogging of fish gills and some Cyanophyceae are also known to produce toxins (Vasconcelos, 2001). Data on diel feeding regime indicated that $O$. niloticus is a diurnal feeder (Otieno et al., 2014). While (Shalloof and Khalifa, 2009; Abidemi-Iromini, 2019) mentioned that the most preferable food of plant origin for $O$. niloticus were diatoms, represented about $68.0 \%$ from the total gut content. (Otieno et $a l ., 2014)$ stated that the major diet of fish $<10 \mathrm{~cm}$ total length were zooplankton and algae. Moreover, the result of this study agree with (Shallof and El-Far, 2009) findings where they mentioned that diatoms in the fish stomachs were represented mainly by Cyclotella spp. and Achnanthes spp. while green algae were represented mostly by Scenedesmus spp. and Coelastrum spp. (Wakil et al., 2014) stated that $O$. niloticus preferred to Chlorella, Scenedesmus and Pediastrum from cholorophyceae.

On the other hand, the average condition factors $(\mathrm{K})$ of the two fish species were generally lower than that reported by (Adam, 2004) for the years between 1984 and 2000. This suggests that the current condition of Lake Nasser, in comparison to its former status, may be becoming unfavourable to fishes.

The length, weight and condition factor data reflect, through its variations, information on the physiological state of the fish in relation to its welfare. From a nutritional point of view, there is the accumulation of fat (Le Cren, 1951). From a reproductive point of view, the highest $\mathrm{K}$ values are reached in some species depending on gonad development (Angelescu et al., 1958). K also gives information when comparing two populations living in certain feeding, density, climate, and other conditions; when determining the period of gonad maturation; and when following up the degree of feeding activity of a species to verify whether it is making good use of its feeding source (Weatherly, 1972).

Both investigated species showed significant difference in mean total length, mean total weight and mean condition factor in different geographical areas of the lake. These differences could be related to spatially different environmental and biological factors and also to the characteristics of the fishing area. The environmental and biological factors include temperature, salinity, food (quantity, quality and size), habitat, gonad development, spawning period, season, sex, small individuals' absence and health (Froese, 2006; Pauly, 1984; Safran, 1992). Fishing time, fishing gear and area may be additional causes of such variation (Ricker, 1973). As the average values of all investigated biological parameters were always higher in southern sector of the lake, this could be an indication that the environmental and biological factors are 
more favourable in this part of the lake. Nevertheless, the results of this study showed that $O$. niloticus and $S$. galilaeus prefer and also avoid the same phytoplankton in their diet at all sectors without any statistical significant difference which indicates that the species and spatial variation in their fisheries biological parameters in Lake Nasser are not related to their feeding activity.

\section{CONCLUSION}

This study shows the importance of phytoplankton as food items for O. niloticus and $S$. galilaeus in Lake Nasser. They fed mainly on Bacillariophyceae followed by Chlorophyceae. The feeding on phytoplankton profiles of the two fish species were similar in all lake sectors while the fisheries biological parameters of the two fish species varied significantly among species and lake sectors. Therefore, it could be concluded that the variation in fisheries biological parameters of the studied fish species in Lake Nasser is not related to their pattern of feeding on phytoplankton but is led by other factors (e.g. fishing practices).

\section{ACKNOWLEDGEMENT}

The running expenses of this study were funded by The National Institute of Oceanography and Fisheries, Egypt, as a part of its project "Evaluation and improvement of Lake Nasser natural resources".

\section{REFERENCES}

Abdel-Tawwab, M. (2003). Occurence of Phytoplankton in Stomach Content and Its Selectivity by Nile Tilapia (Oreochromis niloticus L.) Cultured in Fertilized Earthen Ponds. Qatar University Journal, 23: 153- 166.

Abdulhakim, A.; Addo, S.; Lawan, Z. A. and Ebenezer, A. (2015). Feeding habits and condition factor of Oreochromis niloticus in Lake Alau, Northeastern Nigeria. Algae, 32: 23-36.

Abidemi-Iromini, A. O. (2019). Assessment of stomach contents of Oreochromis niloticus from the Lagos Lagoon, Nigeria. International Journal of Fisheries and Aquaculture, 11(1): 1-6.

Adam, E. A. (2004). Stock assessment of some important commercial fish species of Lake Nasser, Egypt. Assiut Univ, Egypt.

Anene, A. (2005). Condition factor of four Cichlid species of a man-made lake in Imo State, Southeastern Nigeria. Turkish Journal of Fisheries and Aquatic Sciences, 5(1): 43-47.

Angelescu, V.; Gneri, F. S. and Nani, A. (1958). La merluza del Mar Argentino (Biología y Taxonomía).

APHA (1998). Standard methods for the examination of water and wastewater. 20th Ed. New York.

Assefa, W. W. and Getahun, A. (2015). The food and feeding ecology of Nile tilapia, Oreochromis niloticus, in Lake Hayq, Ethiopia. International Journal of Ecology and Environmental Sciences, 41(1-2): 55-65.

Bishai, H. M. and Khalil, M. T. (1997). Freshwater fishes of Egypt: Egyptian Environmental Affairs Agency.

Borowitzka, M. A. and Borowitzka, L. J. (1988). Micro-algal biotechnology: Cambridge University Press. 
Bourrelly, P. (1981). Les algues d'eau douce: Les Algues jaunes et brunes, Chrysophycées, Pheophycées, Xanthophycées, et Diatomées: Société Nouvelle des Éditions Boubée.

Bwanika, G. N.; Makanga, B.; Kizito, Y.; Chapman, L. J. and Balirwa, J. (2004). Observations on the biology of Nile tilapia, Oreochromis niloticus L., in two Ugandan crater lakes. African Journal of Ecology, 42: 93-101.

Canonico, G. C.; Arthington, A.; McCrary, J. K. and Thieme, M. L. (2005). The effects of introduced tilapias on native biodiversity. Aquatic Conservation: Marine and Freshwater Ecosystems, 15(5): 463-483.

Chrisafi, E.; Kaspiris, P. and Katselis, G. (2007). Feeding habits of sand smelt (Atherina boyeri, Risso 1810) in Trichonis Lake (western Greece). Journal of Applied Ichthyology, 23(3): 209-214.

Compère, P. (1991). Contribution à l'étude des algues du Sénégal 1. Algues du lac de Guiers et du Bas-Sénégal. Bulletin du Jardin botanique national de Belgique/Bulletin van de Nationale Plantentuin van Belgie: 171-267.

Desikachary, T. V. (1959). Cyanophyta, ICAR Monograph on algae. New Delhi: 686.

Ekpo, I. E.; Ibok-Essien, M. and Nkwoji, J. N. (2014). Food and feeding habits and condition factor of fish species in Qua Iboe River estuary, Akwa Ibom State, southeastern Nigeria. Int. J. Fish. Aquat. Stud, 2(2): 38-46.

Euzen, O. (1987). Food habits and diet composition of some fish of Kuwait. Kuwait bulletin of marine science, 9(9-10): 65-85.

Froese, R. (2006). Cube law, condition factor and weight-length relationships: history, meta-analysis and recommendations. Journal of Applied Ichthyology, 22(4): 241-253.

GAFRD (2018). General Authority for Fish Resources Development 2016 Fish Statistics Yearbook,. In GAFRD (Ed.), (Vol. 26, pp. 118). Egypt: Ministry of Agriculture.

Gerking, S. D. (2014). Feeding ecology of fish: Elsevier.

Getabu, A. A comparative study on the feeding habits of Oreochromis niloticus (Linnaeus) in Nyanza Gulf Lake Victoria and sewage fish ponds. In, 1994: ICIPE SCIENCE

Getachew, T. (1987). A study on an herbivorous fish, Oreochromis niloticus L., diet and its quality in two Ethiopian Rift Valley lakes, Awasa and Zwai. Journal of Fish Biology, 30(4): 439-449.

Gwahaba, J. J. (1973). Tilapia nilotica is one of the commercially important fish species of the African genus Tilapia. East Afr. Wildl. J, 11: 317.

Halls, A.; Nasr-Allah, A. and Dickson, M. (2015). Lake Nasser fisheries: Literature review and situation analysis.

Hussian, A. E.; Napiórkowska-Krzebietke, A.; Toufeek, M. E. F.; El-Monem, A. M. A. and Morsi, H. H. (2015). Phytoplankton response to changes of physicochemical variables in Lake Nasser, Egypt. Journal of Elementology, 20(4).

Hyslop, E. J. (1980). Stomach contents analysis - a review of methods and their application. Journal of Fish Biology, 17(4): 411-429.

Le Cren, E. D. (1951). The length-weight relationship and seasonal cycle in gonad weight and condition in the perch (Perca fluviatilis). The Journal of Animal Ecology: 201-219.

Lind, O. T. (1974). Handbook of common methods in limnology: St. Louis, The CV Mosby Co. 
Manko, P. J. V. P. u., Prešov, Czech Republic (2016). Stomach content analysis in freshwater fish feeding ecology.

Njiru, M.; Okeyo-Owuor, J. B.; Muchiri, M. and Cowx, I. G. (2004). Shifts in the food of Nile tilapia, Oreochromis niloticus (L.) in Lake Victoria, Kenya. African Journal of Ecology, 42(3): 163-170.

Omondi, R.; Yasindi, A. W. and Magana, A. (2011). Spatial and temporal variations of zooplankton in relation to some environmental factors in Lake Baringo, Kenya. Egerton Journal of Science \& Technology, 11: 29-50.

Oronsaye, C.; Nakpodia, F. J. P. J. o. S. and Research, I. (2005). A comparative study of the food and feeding habits of Chrysichthys nigrodigitatus and Brycinus nurse in a tropical river. 48(2): $118-121$.

Otieno, O. N.; Kitaka, N. and Njiru, J. M. (2014). Some aspects of the feeding ecology of Nile Tilapia, Oreochromis niloticus in Lake Naivasha, Kenya. International Journal of Fisheries and Aquatic Studies, 2(2): 1-8.

Pauly, D. (1983). Some simple methods for the assessment of tropical fish stocks (Vol. 234): Food \& Agriculture Org.

Pauly, D. (1984). Fish population dynamics in tropical waters: a manual for use with programmable calculators (Vol. 8): WorldFish.

Pinkas, L.; Oliphant, M. S. and Iverson, I. L. K. (1970). Fish Bulletin 152. Food Habits of Albacore, Bluefin Tuna, and Bonito In California Waters.

Prescott, G. W. (1978). How to know the freshwater algae.

Ricker, W. E. (1973). Linear regressions in fishery research. Journal of the fisheries board of Canada, 30(3): 409-434.

Safran, P. (1992). Theoretical analysis of the weight-length relationship in fish juveniles. Marine Biology, 112(4): 545-551.

Saiyida, N. and Bari, G. A. (1982). Gut contents of Haleji Lake fishes for determination of the importance of phytoplankton as fish food. Pakistan Journal of Agricultural Research, 3(3): 156-169.

Shallof, K. A. and El-Far, A. M. (2009). Age, growth and fishery biology of cichlid spp inAbu-Zaabal Lakes, Egypt. . Egypt J. Aquat. Biol. Fish, 13: 101-116.

Shalloof, K. A. S. and Khalifa, N. (2009). Stomach contents and feeding habits of Oreochromis niloticus (L.) from Abu-Zabal lakes, Egypt. World Applied Sciences Journal, 6(1): 1-5.

Starmach, K. (1974). Cryptophyceae--kryptofity, Dinophyceae--Dinofity, Raphidophyceae--rafidofity. Flora Slodkowodna Pol Pol Akad Nauk Inst Bot.

Strauss, R. E. (1979). Reliability Estimates for Ivlev's Electivity Index, the Forage Ratio, and a Proposed Linear Index of Food Selection. Transactions of the American Fisheries Society, 108(4): 344-352.

Tadesse, Z. (1998). Food and feeding ecology of tilapia, Oreochromis niloticus L. and effects of diet on the lipid quality of fish in some lakes in Ethiopia. (Ph.D. dissertation, School of Graduate studies, Addis Ababa University, Addis Ababa).

Teferi, Y.; Admassu, D. and Mengistou, S. (2000). The food and feeding habit of Oreochromis niloticus L.(Pisces: Cichlidae) in Lake Chamo, Ethiopia. SINET: Ethiopian Journal of Science, 23(1): 1-12.

Tiffany, L. H. and Britton, M. E. (1952). The algae of Illinois. The University of Chicago press. Chicago.

Vasconcelos, V. (2001). Cyanobacteria toxins: diversity and ecological effects. Limnetica, 20(1): 45-58. 
Vollenweider, R. A.; Talling, J. F. and Westlake, D. F. (1974). A manual on methods for measuring primary production in aquatic environments: Blackwell Scientific Pub.

Wakil, U. B.; Haruna, A. B.; Mohammed, G. A.; Ndirmbita, W. L.; BUKAR-KOLO, M. Y. and MOHAMMED, U. K. (2014). Examinations of the stomach contents of two fish species (Clarias gariepinus and Oreochromis niloticus) in Lake Alau, North-Eastern Nigeria. Agriculture, Forestry and Fisheries, 3(5): 405-409.

Weatherly, A. H. (1972). Growth and Ecology of Fish Populations. London: Academic Press.

Windell, J. T. and Bowen, S. H. (1978). Methods for study of fish diets based on analysis of stomach contents. IBP Handbook (IBP). no. 3.

YalÇIn, Ş. Ö.; Akyurt, İ. and Solak, K. (2001). Stomach contents of the catfish (Clarias gariepinus Burchell, 1822) in the River Asi (Turkey). Turkish Journal of Zoology, 25(4): 461-468. 